Погребняк Л.О., к.т.н., доч., ДДУУ, м. Маріуполь, ORCID: 0000-0003-2836-5610

Pogrebnyak L., Ph.D., Associate Professor of Environmental Management, Donetsk State University of Management, Mariupol

\title{
ОРГАНІЗАЦІЙНО-ПРАВОВІ МЕХАНІЗМИ ДЕРЖАВНОГО УПРАВЛІННЯ ОЗЕЛЕНЕННЯМ МІСТ УКРАЇНИ
}

\section{ORGANIZATIONAL AND LEGAL MECHANISMS OF STATE MANAGEMENT OF LANDSCAPING OF UKRAINIAN CITIES}

Визначені недоліки організаційно-правового регулювання державної політики України у сфері озеленення населених пунктів та їх причини, обов'язки державних органів влади та органів місиевого самоврядування з утримання та догляду за об'єктами озеленення та надані рекомендащії щодо шляхів удосконалення організаційно-правових механізмів держсавного управління озелененням міст.

Ключові слова: організачійно-правові механізми, озеленення, екологічна система, самоврядування, навколишнє природне середовище.

Identified shortcomings of organizational and legal regulation of state policy of Ukraine in the field of landscaping and their causes, the responsibilities of state authorities and local governments to maintain and care for landscaping and provided recommendations on how to improve the organizational and legal mechanisms of state urban landscaping management.

Keywords: organizational and legal mechanisms, greening, ecological system, selfgovernment, environment.

Постановка проблеми. В умовах глобалізованого світу, переживаючи період трансформації системи державного управління та суспільства, Україна постала перед низкою викликів, що потребують прийняття термінових рішень. Незбалансована експлуатація ресурсів природи, нехтування пріоритетами захисту довкілля, що десятиліттями супроводжувало економічний розвиток країни, призвели до критичних екологічних наслідків для навколишнього природного середовища.

Незадовільний екологічний стан соціо-екологічної системи України можна пояснити наступними основними причинами [1, 9-14]:

- превалювання економічних пріоритетів над екологічними потребами;

- високий рівень ресурсо- та енергоємності виробництв, які, здебільшого, негативно впливають на екологічний стан довкілля; 
- багаторічне нехтування у правовому полі країни потребами довкілля;

- недостатнє врахування негативних наслідків для навколишнього природного середовища у законодавстві;

- високий рівень зношеності основних виробничих фондів у більшості галузей економіки (до 90\%);

- недостатньо ефективне функціонування державної системи моніторингу якості навколишнього природного середовища;

- низький рівень ефективності системи державного управління сферою охорони навколишнього природного середовища;

- низький рівень взаємодії та узгодженості державних, регіональних, місцевих органів влади та органів місцевого самоврядування;

- низький рівень поінформованості, екологічної культури та свідомості суспільства;

- неефективність системи екологічної освіти та нехтування державою іiї проблемами та потребами;

- нехтування органами влади та місцевого самоврядування дотриманням законодавства з охорони природи та екологічних повноважень громадян;

- недостатність виконання функцій контролю та нагляду з боку органів влади та відсутність невідворотності відповідальності та покарання за порушення екологічного законодавства;

- недостатність бюджетного фінансування природоохоронних заходів, які здійснюються, зазвичай, у залишковий спосіб;

- у країні відсутня комплексна програма поводження із зеленими насадженнями, що призводить до зменшення площі зелених зон у населених пунктах, неповноцінного догляду за ними та відновлення втрачених рослин;

- у законодавстві відсутні дієві інструменти впливу на відповідальних осіб виконавчої влади, власників підприємств, представників бізнесу тощо. за допущені правопорушення з не проведення моніторингу стану озеленення міст, відсутності паспортів з благоустрою територій, невиконання планів, програм, стратегій озеленення, за несплату компенсації з відновлюваної вартості втрачених рослин;

- у законодавстві відсутні дієві інструменти контролю з боку Державної екологічної інспекції правопорушень поводження із рослинними насадженнями;

- критична недостатність у експертах - спеціалістах 3 управління системою озеленення населеного пункту;

- непоодинокі випадки проведення експертизи, огляду, моніторингу стану зелених насаджень без залучення експертів - фахівців та надання їх експертного висновку;

- законодавством не визначені терміни і строки настання відповідальності за адміністративні правопорушення з охорони зелених насаджень спеціальними органами після складання відповідних протоколів;

- відсутність повноважень у інспекторів Державної екологічної інспекції стосовно оперативного реагування на правопорушення;

132 
- відсутність відкритого переліку громадських інспекторів з охорони навколишнього природного середовища та обмеженість їх повноважень стосовно реагування на правопорушення;

- обмеженість кола організацій та осіб, які мають повноваження для складання протоколів за правопорушення та притягнення до адміністративної, кримінальної відповідальності винних у правопорушеннях;

- відсутність вимог на обов'язкове отримання дозвільних документів будівельними організаціями на порушення зелених насаджень для отримання дозвільних документів;

- відсутність у сфері управління системою озеленення міст України інституту нагляду за дотриманням вимог законодавства, що призводить до неефективності інструментів контролю;

- відсутність доступної, достовірної електронної системи обліку наявних зелених зон та їх екологічного стану, як на загальнодержавному, так і на місцевому рівнях.

На сьогодні, регламентуюча діяльність органів влади у сфері управління зеленими насадженнями здійснюється органами влади усіх рівнів, через Кабінет Міністрів, який формує та забезпечує державну політику у галузі житловокомунального господарства, до місцевих органів виконавчої влади (за допомоги спеціально уповноважених органів та громадськості), які здійснюють державний і громадянський контроль у містах та інших населених пунктах за виконанням державної політики з формування, розвитку та охорони системи озеленення.

Аналіз останніх досліджень і публікацій. Слід зазначити, що природоохоронне законодавство України, на тлі процесів глобалізації та намірів України до інтеграції із країнами ЄС (з часів підписання у 1994 році Угоди про партнерство і співробітництво між Україною, Європейськими співтовариствами та їх державами - членами), потребує глибокого реформування з метою свого приведення до стандартів та вимог європейського екологічного законодавства.

Окремої уваги потребує Закон України «Про Основні засади (стратегію) державної екологічної політики України на період до 2030 року», прийнятий наприкінці 2019 року після двох років обговорень відповідного законопроекту. На жаль, попередньо прийнятий аналогічний документ, розрахований теж на 10 років своєї дії (2010 - 2020pp.), не досяг поставлених цілей, і на те було багато причин економічного, політичного i, навіть, воєнного характеру, які важко було спрогнозувати під час прийняття закону.

За прогнозами, Україна, як і більшість інших держав світу, найближчим часом стикнеться із критичними, навіть, катастрофічними екологічними викликами, спровокованими кумулятивними ефектами у сфері наявності ресурсів, екологічного стану своєї території, кліматичних змін глобального характеру. Тим більш, накопичені екологічні проблеми загострилися ще більше у зв’язку із необхідністю брати участь у воєнному протистоянні з країною-агресором, що потребує використання великих коштів із державного бюджету i, звісно, фінан- 
сування заявлених екологічних програм та заходів значно зменшилося. На думку Балюка Г.І. [1] стратегічні цілі і завдання, які передбачені даною Стратегією, «..можуть бути досягнуті виключно шляхом одночасного вирішення економічних, соціальних і екологічних проблем», що відповідає екологічній політиці України у їі прагненні до стійкого розвитку. На жаль, продовжує автор, серед принципів, якими потрібно керуватися для реалізації державної екологічної політики «..відсутні такі, як: наукова обгрунтованість, законність, передбачуваність, справедливість, поєднання інтересів особи, суспільства і держави, пріоритетність екологічних прав людини, відповідність міжнародним правовим стандартам.»

I досі екологічне законодавство нашої держави страждає на велику кількість недоліків, що призводить до дублювання, неможливості узгодження окремих нормативно-правових документів, актів, виникнення суперечностей у їх тлумаченні та труднощам у їх використанні на практиці $[1,3,5]$.

Проблемами та питаннями реформування українського законодавства 3 охорони природи, починаючи із 90-х років ХХ століття, переймаються багато науковців - фахівців з екологічного права. Це такі вчені - правознавці, як А. Гетьман, Г.Балюк, В. Андрейцева, А. Бобкова, Г. Анісімова, В. Костицький, Н. Малишева та інші.

Наукова стаття Блавацької Д.І. присвячена питанню реформування екологічного законодавства України, як провідного напрямку ії екологічної політики [3]. Автором проаналізовано стан чинного природоохоронного законодавства, визначені його проблеми та недоліки, які потребують виправлення, доповнення, уточнення та, у цілому, формування «еколого - правової доктрини».

Місце та значення права у інституті управління природокористуванням та охороною довкілля визначає Гетьман А. П. [5], наголошуючи, що, на жаль, фахівці з екологічного, адміністративного права занадто мало уваги приділяють питаннях його верховенства у процесі «правової організації державної влади у суспільстві» та надання юридичних гарантій громадянам і юридичним особам у захисті їх екологічних свобод, прав та інтересів.

Різноманітним аспектам благоустрою населених пунктів та визначенням можливостей органів місцевого самоврядування у забезпеченні дотримання екологічних прав громади присвячені роботи Безлюбченка О. [2], Богової I. [4], Гудима М. [6], Ігнатенко О. [7], Кучерявого В.[8], Вакуленка В., Орлатого М. [16] та ін. Автори визначають коло повноважень державної та місцевої влади у плануванні, організації, розвитку, відтворенні, охороні екологобезпечного простору міста, впроваджуючи новітні технології у сфері містобудування та системи міських фітоценозів.

Метою дослідження визначено надання рекомендацій щодо шляхів удосконалення організаційно - правових механізмів державного управління озелененням міст України.

Виклад основного матеріалу. Головне навантаження з реалізації державної політики з охорони навколишнього природного середовища несуть органи 134 
місцевого самоврядування, які відповідають, у межах своєї компетенції та повноважень, за екологічний стан власної території; реалізацію прав громадян, визначених законодавством, на безпечне та здорове навколишнє природне середовище; регулюють питання розміщення на території населеного пункту підприємств, установ чи організацій; затверджують генеральні плани та проекти забудови $з$ урахуванням екологічних вимог; розпоряджаються дозволами на використання місцевих природних ресурсів; розробляють та реалізовують місцеві екологічні стратегії, програми, проекти у рамках екологічної політики міста та держави; залучають інвестиції, створюють спеціальні фонди 3 фінансування екологічних потреб міста; залучають до вирішення екологічних проблем громадські організації та населення міста; замовляють та організують, за потреби, проведення екологічної експертизи, аудиту, моніторингу екологічного стану території чи окремих зон міста; контролюють діяльність об єктів господарської діяльності та іiі відповідність вимогам природоохоронного законодавства, навіть до іiі обмеження чи припинення; систематично та оперативно інформують населення, громаду про екологічний стан навколишнього природного середовища; організують екологічну освіту, виховання, підвищення екологічної культури, свідомості та відповідальності громадян [2, 4, 6-8, 13, 15].

Владні функції виконуються спеціально на те уповноваженими органами влади міста - міської ради. Громадські послуги надаються комунальними підприємствами та суб'єктами господарювання різних форм власності.

До міських функцій самоврядування також належать [2, 7, 16]:

- управління, на правах власника, муніципальною, комунальною власністю та їі використання;

- комплексний соціально-економічний та екологічний розвиток міста;

- забезпечення дотримання соціальних прав, свобод, інтересів громадян, надання їм соціальних послуг;

- залучення громадян до співпраці у питаннях місцевого та державного значення;

- створення умов для безпечної життєдіяльності населення, забезпечення законності та правопорядку;

- захист екологічних прав населення на безпечне навколишнє природне середовище.

Зважаючи на критичний екологічний стан соціо- екологічної системи України, слід відмітити, що особливо деградуючі зміни відбуваються у рослинному світі країни, ресурси якого вичерпуються швидкими темпами по усій території держави.

До рослинних об'єктів, утримання, відтворення та охорона яких регулюється законодавством України про зелені насадження, відносяться [9, 12, 13]:

- зони озеленення міських та районних рекреаційних парків, скверів, спортивних та дитячих майданчиків, об'єктів природно-заповідного фонду, зоопарків, ботанічних садів, лісопарків, прибудинкових та міжбудинкових майданчиків, набережних, гідропарків, що відносяться до територій загального кори- 
стування;

- насадження обмеженого користування прибудинкових майданчиків, дошкільних, шкільних, середніх і вищих закладів освіти та виховання, закладів охорони здоров 'я, територій промислових підприємств, складів, об’єктів санаторно-курортного призначення, культурно-просвітницьких та спортивних тощо;

- насадження спеціального користування, розташовані вздовж транспортної інфраструктури, у санітарно-захисних зонах, кладовищах, вздовж високовольтних ліній електромереж, на спустошених грунтах, лісомеліоративних, водота вітрозахисних смуг, господарств квітникарства та розсадництва тощо.

Згідно законодавства, головною функцією рослинних насаджень населених пунктів, як важливого природного елементу соціо - екологічної системи $\epsilon$ забезпечення здорових, оптимальних, найбільш сприятливих умов життєдіяльності населення. Особливі зобов' язання щодо здійснення контролю за станом та забезпеченням належного догляду озеленених територій накладаються на власників та користувачів земельних ділянок, на органи місцевого самоврядування, які розробляють та реалізують генеральні плани розвитку міст з обов'язковим врахуванням розміщення, охорони, збільшення питомої ваги насаджень і максимального збереження вже існуючих.

Законодавством визначено наступні вимоги щодо площ озеленення [9, 12, 13]:

- питома вага площ загального користування у місті - не менше 25 м2/люд.;

- в інших населених пунктах - не менше 20 м2/люд.

За рівнем озеленення забудов по відношенню до загальної площі розподіл наступний:

- житлової забудови - не менше 40\%;

- ділянок дошкільних і шкільних закладів - не менше 80\%;

- лікарень - не менше 60\%;

- промислових підприсмств - не менше 30\%.

Окремої уваги та піклування потребують території, віднесені до природно-заповідного фонду, на яких заборонена будь яка діяльність, що не дозволена чинним законодавством.

До обов’язків державних органів влади та органів місцевого самоврядування відносяться наступні виконавчі функції:

- утримання та догляд за об’єктами зелених насаджень згідно затверджених центральним органом виконавчої влади «Правил утримання зелених насаджень у населених пунктах України»[12], які забезпечують формування та реалізацію державної і регіональної житлової політики у сфері охорони навколишнього природного середовища;

- визначення, на конкурсній основі (не частіше одного разу за п'ять років), балансоутримувачів зелених насаджень, власником яких є міська Рада;

- відповідальність за охорону та збереження зелених насаджень покладена на балансоутримувачів, власників, користувачів земельних ділянок, забудов136 
ників та власників ділянок, переданих під забудівлю, органи місцевого самоврядування, підприємства, установи, організації, на території яких розміщенні зелені ділянки;

- догляд за озелененими зонами у містах здійснюють спеціалізовані підприємства комунальної власності на умовах договору із власником (міською радою) [15].

Висновки. На жаль, політика України з управління озелененням міст, на сьогодні, не тільки не спрямована на створення нових та розвиток вже існуючих зелених зон у містах країни, а навпаки, спостерігається поступове скорочення озеленених зон, які передаються під житлові чи комерційні забудови, будівництво доріг та інших об'єктів інфраструктури. Більшість населених пунктів, особливо промислових міст, несуть втрати зон рекреації та погіршення стану індивідуального та соціального здоров я громади, стикаються із проблемою заподіяння шкоди благоустрою та міського довкілля, залишаються без повноцінної, природної системи очищення повітря.

Визначення основних екологічних проблем соціо- екологічної системи країни та встановлення джерел, причин і наслідків, які сприяли появі цих проблем, дозволяє надати наступні рекомендації з управління сферою охорони екологічного простору України, її населених міст з їх подальшим закріпленням у природоохоронному законодавстві:

- забезпечити підготовку фахових кадрів у системі Державної екологічної інспекції щодо проведення інспекторських перевірок та надання експертних оцінок відповідності законодавству процедур поводження із зеленими насадженнями;

- зобов язати відповідальних осіб органів місцевого самоврядування створити та наповнювати регулярно (із визначенням термінів виконання) відкриті електронні системи обліку зелених насаджень населеного пункту, забезпечити оприлюднення та відкритість даних інвентаризації та паспортизації зелених господарських об єктів;

- необхідно створення місцевого, міського Фонду охорони довкілля через відповідні правові процедури. Джерелами наповнення такого Фонду визначити:

- кошти за відшкодування заподіяної довкіллю шкоди;

- надходження від накладених штрафних санкцій за правопорушення у сфері охорони навколишнього природного середовища, кошти яких повинні у повному обсязі направлятися у місцевий Фонд;

- надходження на добровільній основі від благодійних організацій чи фізичних осіб, громадських організацій, підприємців, власників об'єктів господарства (у тому числі іноземних) тощо.;

- надходження від додаткових екологічних податків, накладених на об'єкти господарства, розташовані на території відповідальності органів місцевого управління, виробнича діяльність яких супроводжується додатковими ризиками $з$ надання шкоди атмосферному повітрю, водним та земельним ресурсам, екологічному стану зелених насаджень населеного пункту, його природно- 
го ландшафту, біорізноманіттю міської екосистеми, стану здоров я та тривалості життя населення.

Вирішення проблеми відсутності відповідальності за порушення законодавства $з$ охорони рослинного світу (знищення, видалення, самовільне перенесення, пошкодження насаджень рослин або окремих рослинних об'єктів, недотримання вимог щодо їх охорони, обстеження, догляду, надання неправдивих даних, підробка дозвільних документів, несплата вчасно відновної вартості рослин, порушення вимог до правил і порядку поводження із зеленими насадженнями) необхідне внесення змін з підвищення накладених штрафів на громадян у Кодекс адміністративних правопорушень України від 70 до 100 неоподатковуваних мінімумів їх доходів.

Аналогічні штрафні санкції повинні накладатися за порушення законодавства України з охорони довкілля, а саме зелених насаджень, про порядок та ігнорування проведення процедури їх інвентаризації, охорони та догляду, необхідності формування та невиконання відповідних програм.

У разі адміністративного правопорушення за недотримання строків складання та надсилання адміністративних протоколів до уповноважених органів розглядання справи необхідне підвищення накладених штрафів на відповідних посадових осіб до 100 неоподатковуваних мінімумів їх доходів.

Необхідно встановити чіткі строки надання складеного протоколу про адміністративне правопорушення до уповноваженого органу 3 розглядання справи у три робочі дні від часу складення.

Також, пропонується обов'язкове оприлюднення 1 січня кожного року на сайтах Державної екологічної інспекції України, їі територіальних підрозділів, органів місцевого самоврядування Переліку (реєстру) громадських інспекторів.

Для створення і забезпечення вчасного та оперативного реагування органів контролю на правопорушення з охорони рослинного світу необхідно надання їм можливості у здійсненні позапланових перевірок, підставами для яких $є$ обгрунтовані запити від фізичних та юридичних осіб про випадки скоєних порушень їх законних прав суб'єктами господарювання чи окремими фізичними особами. Стосовно осіб, що надали необгрунтоване звернення, передбачити законодавчу відповідальність.

Запропоновані зміни мають бути відображеними у Законі України «Про основні засади державного нагляду (контролю) у сфері господарської діяльності». Забезпечити більш ускладнену процедуру надання дозвільної документації iз видалення зелених насаджень та проведення заходів із поводження з рослинами шляхом внесення відповідних змін у Закони України «Про регулювання містобудівної діяльності» та «Про благоустрій населених пунктів».

Внести необхідні зміни у «Правила утримання зелених насаджень у населених пунктах України, затверджених Наказом Міністерства будівництва України від 10.04.2006 № 105” з накладання обов ‘зків на органи місцевого самоврядування до 20 грудня кожного року розробити і затвердити комплексну програму озеленення населеного пункту на наступний рік, до 25 листопада надати 138 
звіт із виконання аналогічної програми поточного року, покласти здійснення контролю за виконанням та формуванням таких програм на Державну екологічну інспекцію України та їі територіальні підрозділи.

Забезпечити усунення недоліків законодавства у сфері поводження із рослинними ресурсами за допомогою розроблення та прийняття нормативноправового акту, яким передбачити правила отримання дозвільних документів у випадках необхідності здійснення порушень насаджень чи окремих рослин (дерев, кущів, чагарників, газонів, вертикальних, бар`єрно-архітектурних квіткових конструкцій тощо).

Надати більш чіткі, науково обгрунтовані визначення термінів і понять, що використовуються у «Правилах утримання зелених насаджень у населених пунктах України, затверджених Наказом Міністерства будівництва України від 10.04.2006», переглянути строки експлуатації зелених насаджень у бік їх збільшення. Забезпечити розроблення та прийняття «Положення про відкриті електронні системи обліку зелених насаджень у населених пунктах», у якому передбачити обов'язки державних органів влади та органів місцевого самоврядування із створення та постійного ведення такої системи обліку, яка повинна містити інформацію про кількість, щільність, питому вагу системи зелених насаджень населеного пункту, їх екологічний стан, облік правопорушень та стану реагування на них відповідних органів тощо.).

Законодавчо забезпечити розроблення та прийняття спеціального нормативно-правового Акту про призначення відповідальної особи у складі міської Ради з покладанням на неї обов'язків нагляду та контролю за екологічним станом довкілля, його охорони у населеному пункті.

Для удосконалення державного регулювання сфери благоустрою населених пунктів в Україні також можна запропонувати наступні дії:

- забезпечити процес децентралізації повноважень у сфері благоустрою населених пунктів 3 правом встановлення спеціальних місцевих податків місцевими органами влади, спрямованих на створення та використання відповідних фінансових фондів місцевих бюджетів;

- забезпечити широку демократизацію системи управління сферою благоустрою;

- запроваджувати демократичні форми системи управління населених пунктів, у тому числі з використання можливостей акціонування, здачі в оренду, продажу комунальних підприємств із залученням організацій різних форм власності;

- застосовувати методи мотивації та стимулювання із запровадження інноваційних технологій управління сферою благоустрою та озеленення населених пунктів;

- формувати спеціальних державні, регіональні та місцеві фонди для проведення конкурсів щодо надання інвестицій в розвиток сфери озеленення населених пунктів; 
- запровадити принципи обов'язковості, соціального партнерства стосовно проведення конкурсних змагань у сфері благоустрою населених пунктів між претендентами на інвестиційне фінансування;

- запровадити в Законі України «Про місцеве самоврядування в Україні» демократичний принцип «обов'язковості» та «необов'язковості» комунальних послуг, який передбачає розширення можливостей користувача у сфері благоустрою;

- розробити законодавство із розподілу платників місцевих податків за принципом «обов’язковості» та «добровільності»;

- всебічно розвивати зв'язки та співпрацю між державними та місцевими органами влади, громадою, підприємцями, власниками приватного бізнесу, муніципалітетами інших міст України та країн ЄC;

- використовувати ринкові інструменти економіки у співпраці 3 підвищення ефективності озеленення міст та територій;

- використовувати ринкові можливості тарифного (цінового) регулювання надання послуг;

- проводити регулярно діяльність із системного моніторингу і контролю екологічного стану зелених зон міста та підвищення рівня особистої відповідальностіперед органами державної влади та громадськістю.

Органи міського управління можуть також сприяти збереженню біорізноманіття та екосистем на своїх територіях через:

- визначення необхідності збереження біорізноманіття у своїй екологічній політиці, програмах та стратегіях розвитку;

- створення на території міста об’єктів природно-заповідного фонду;

- створення та розширення інфраструктурної міської мережі для забезпечення оптимального доступу громадян до зон озеленення;

- проведення інформаційно-рекламних кампаній, заходів для формування та підвищення іміджевого рівня міста;

- прийняття необхідних рішень управління системою озеленення 3 урахуванням екологічних потреб фітоценозів та населення;

- ефективного використання у політиці благоустрою фінансових механізмів;

- підтримку ініціативи громади та громадських організацій з охорони довкілля та збереження біофонду.

\section{Список використаних джерел:}

1. Балюк Г.І. Правові засади державної екологічної політики України: сучасні проблеми. Екологічне право України. 2017. № 3-4 . С. 8-15.

2. Безлюбченко О.С. Планування і благоустрій міст : навч. посібник. для студентів усіх форм навчання та слухачів другої вищої освіти за напрямом 140 
підготовки 0921 (6.060101) - «Будівництво» / О. С. Безлюбченко, О. В. Завальний, Т. О. Черноносова: Харк. нац. акад. міськ. госп-ва. Х.: ХНАМГ, 2011. $191 \mathrm{c.}$

3. Блавацька Д.А. Реформування екологічного законодавства України провідний напрямок державної екологічної політики. Теорія і практика правознавства. Вип. 2(8). 2015. С. 1-13.

4. Боговая И.О., Теодоронский В.С. Озеленение населенных мест. М.: Лань, 2012. $241 \mathrm{c}$.

5. Гетьман А.П. Верховенство права в інституті управління природокористуванням та охороною довкілля. Екологічне право України. 2017. № 3-4. C. $2-8$.

6. Гудим М.Г., Кудряченко О.П., Гринь С.О. Озеленення міських територій. Альтернативне озеленення. Харків. «Молодий вчений». 2016. №12 (39). C. 33-35.

7. Ігнатенко О.П. Державне регулювання сфери благоустрою населених пунктів: дис. д-ра. наук держупр. Київ, 2016. 460с.

8. Кучерявий В.П., Кучерявий В.С. Озеленення населених місць: підручник для студентів вищих навчальних закладів. Львів, Видавництво «Новий Світ-2000», 2020. 666 с.

9. Наказ Міністерства будівництва, архітектури та житлово-комунального господарства України «Про затвердження Правил утримання зелених насаджень у населених пунктах України» від 10.04.2006 № 105. http://zakon3.rada.gov.ua/laws/

10. Наказ Міністерства екології та природних ресурсів України «Про затвердження Положення про громадських інспекторів 3 охорони довкілля» від 27.02.2002 №88. http://zakon2.rada.gov.ua/laws/

11. Парки замість бетону: нова політика у сфері управління зеленими насадженнями. /Норенко К., Куць Н., Рубель О./Львів «Манускрипт». 2016.$17 \mathrm{c}$.

12. Правила утримання зелених насаджень у населених пунктах України / Наказ Міністерства будівництва, архітектури та житлово-комунального господарства України від 10.04.2006, № 15. http://zakon4.rada.gov.ua/laws/.

13. «Про зелені насадження міст та інших населених пунктів»: Закон України // Відомості Верховної Ради України. - 2012-2021. - № 40. - Ст. 1, 5, 6-8, 10, 15, 19. http://zakon4.rada.gov.ua/laws/

14. «Про рослинний світ: Закон України // Відомості Верховної Ради України. 1999-2021. № 22-23. - Ст. 2-5, 23-30, 39. http://zakon4.rada.gov.ua/laws/

15. «Про місцеве самоврядування в Україні»: Закон України // Відомості Верховної Ради України. 1997-2021. № 24. Ст. 1-3, 24, 26. http://zakon4.rada.gov.ua/laws/

16. Управління сучасним містом: підручник/за ред.. В. М. Вакуленка, М. К. Орлатого. К.: НАДУ, 2008. 632c. 


\section{References:}

1. Balyuk G. Legal bases of the state ecological policy of Ukraine: modern problems. Environmental law of Ukraine. 2017. № 3-4. p. 8-15.

2. Bezlyubchenko O. Urban planning and improvement: textbook. manual. for students of all forms of education and students of the second higher education in the direction of training 0921 (6.060101) - "Construction" / O. Bezlyubchenko, O. Zavalny, T. Chernonosova: Kharkiv. nat. acad. city households. H .: KNAMG, 2011. 191 p.

3. Blavatsky D. Reforming the environmental legislation of Ukraine is the leading direction of the state environmental policy. Theory and practice of jurisprudence. Vip. 2 (8). 2015. p. 1-13.

4. Bogovaya IO., Teodoronsky V. Landscaping of populated areas. M .: Lan, 2012. $241 \mathrm{~s}$.

5. Hetman A. Rule of law in the institute of nature management and environmental protection. Environmental law of Ukraine. 2017. № 3-4 - p. 2 - 8.

6. Gudim M., Kudryachenko O., Grin S. Landscaping of urban areas. Alternative landscaping. Kharkiv. "Young scientist". 2016. №12 (39). P. 33-35.

7. Ignatenko O. State regulation of the sphere of improvement of settlements: dis. Dr. of Sciences Kyiv, 2016. 460 p.

8. Curly V., Curly V. Landscaping of settlements: a textbook for students of higher educational institutions. Lviv, New World-2000 Publishing House, 2020. 666 p.

9. Order of the Ministry of Construction, Architecture and Housing of Ukraine "On approval of the Rules of maintenance of green areas in the settlements of Ukraine" dated 10.04.2006 № 105. http://zakon3.rada.gov.ua/laws/

10. Order of the Ministry of Ecology and Natural Resources of Ukraine "On approval of the Regulations on public inspectors for environmental protection" from 27.02.2002 №88. http://zakon2.rada.gov.ua/laws/

11. Parks instead of concrete: a new policy in the field of green space management. / Norenko K., Kuts N., Rubel O. / Lviv "Manuscript". 2016. 17p.

12. Rules of maintenance of green plantings in the settlements of Ukraine / Order of the Ministry of Construction, Architecture and Housing of Ukraine dated April 10, 2006, № 15. http://zakon4.rada.gov.ua/laws/

13. "On greenery of cities and other settlements": Law of Ukraine // Bulletin of the Verkhovna Rada of Ukraine. 2012-2021. № 40. Ст. 1, 5, 6-8, 10, 15, 19. http://zakon4.rada.gov.ua/laws/

14. "On flora: the Law of Ukraine // Bulletin of the Verkhovna Rada of Ukraine. 1999-2021. № 22-23. St. 2-5, 23-30, 39. http://zakon4.rada.gov.ua/laws/

15. "On local self-government in Ukraine": Law of Ukraine // Bulletin of the Verkhovna Rada of Ukraine. 1997-2021. № 24. Ст. 1-3, 24.26. http://zakon4.rada.gov.ua/laws/

16. Management of the modern city: a textbook / edited by VM Vakulenko, МК Orlatogo. - К.: НАДУ, 2008. 632 с. 